\title{
Grazing impacts of the invasive bivalve Limnoperna fortunei (Dunker, 1857) on single-celled, colonial and filamentous cyanobacteria
}

\author{
Gazulha, V. ${ }^{a *}$, Mansur, MCD. ${ }^{b}$, Cybis, $L F^{a}$ and Azevedo, SMFO. ${ }^{c}$ \\ anstituto de Pesquisas Hidráulicas, Universidade Federal do Rio Grande do Sul - UFRGS, \\ Av. Bento Gonçalves, 9500, CEP 91501-970, Porto Alegre, RS, Brazil

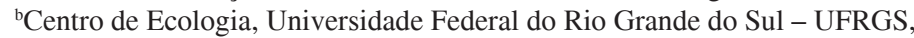 \\ Av. Bento Gonçalves, 9500, Porto Alegre, RS, Brazil \\ 'Instituto de Biofísica Carlos Chagas Filho - IBCCF, Centro de Ciências da Saúde - CCS, Bloco G, \\ Cidade Universitária, Ilha do Fundão, CEP 21949-900, Rio de Janeiro, RJ, Brazil \\ *e-mail: vanessagazulha@gmail.com
}

Received June 19, 2010 - Accepted January 6, 2011 - Distributed February 29, 2012

(With 2 figures)

\begin{abstract}
Feeding behavior of the invasive bivalve Limnoperna fortunei in the presence of single-celled, colonial, and filamentous cyanobacteria was tested in laboratory experiments to evaluate the effects of size and shape on mussel feeding. The first hypothesis holds that golden mussel filters more efficiently smaller particles, such as single cells of Microcystis, which could be more easily assimilated by its filtering apparatus. The second hypothesis sustains that $L$. fortunei filters more efficiently rounded colonies, such as Microcystis, which would be more easily ingested than lengthy filamentous, such as Planktothrix. Filtration rates of golden mussel in the presence of single-celled, colonial and filamentous cyanobacteria were similar. Nevertheless, there was a great difference in the ingestion and pseudofeces production rates. Single cells were widely accepted as food, while filamentous and colonial cyanobacteria were massively expelled as pseudofeces. The results confirmed the first hypothesis that golden mussel prefers to ingest smaller particles. The second hypothesis was rejected since filamentous were preferentially ingested than colonial cyanobacteria. Golden mussel has the potential to remove toxic cells (Microcystis), however this potential would be reduced in cyanobacteria blooms, where colonial forms which are preferentially rejected by $L$. fortune $i$, are predominant. In this case, the presence of this invasive bivalve could also enhance the occurrence of blooms by rejecting colonial and filamentous cyanobacteria in pseudofeces.
\end{abstract}

Keywords: golden mussel, Microcystis, Planktothrix, filtration rates, exotic species.

\section{Impactos da filtração do bivalve invasor Limnoperna fortunei (Dunker, 1857) sobre cianobactérias solitárias, coloniais e filamentosas}

\begin{abstract}
Resumo
O comportamento alimentar do bivalve invasor Limnoperna fortunei na presença de cianobactérias solitárias, coloniais e filamentosas foi testado em experimentos laboratoriais, para avaliar os efeitos do tamanho e da forma na alimentação dos mexilhões. A primeira hipótese sustenta que o mexilhão dourado filtra as partículas menores com maior eficiência, como as células solitárias de Microcystis, as quais seriam assimiladas mais facilmente. A segunda hipótese sustenta que $L$. fortunei filtra com mais eficiência as colônias arredondadas, como Microcystis, que seriam mais facilmente ingeridas do que os filamentos longos, como Planktothrix. As taxas de filtração do mexilhão dourado na presença das cianobactérias solitárias, coloniais e filamentosas foram semelhantes. No entanto, houve uma grande diferença nas taxas de ingestão e produção de pseudofezes. As células solitárias foram amplamente aceitas como alimento, enquanto as cianobactérias filamentosas e coloniais foram massivamente expulsas sob a forma de pseudofezes. Os resultados confirmaram a primeira hipótese, a de que o mexilhão dourado prefere ingerir partículas menores. A segunda hipótese foi rejeitada, pois os filamentosos de Planktothrix foram preferencialmente ingeridos em relação às colônias de Microcystis. O mexilhão dourado apresenta potencial para remover células tóxicas de cianobactérias (Microcystis); entretanto, esse potencial ficaria reduzido em eventos de floração, em que as formas coloniais, preferencialmente rejeitadas por L. fortunei, são predominantes. Nesse caso, a presença do bivalve no ambiente poderia ainda potencializar a ocorrência da floração via rejeição das cianobactérias coloniais e filamentosas nas pseudofezes.
\end{abstract}

Palavras-chave: Mexilhão dourado, Microcystis, Planktothrix, taxas de filtração, espécies exóticas. 


\section{Introduction}

Bivalve feeding mechanisms by filtering particles can strongly influence pelagic and benthic communities, especially when some species occur in large densities. Bivalves play an important role in regulating dynamics of aquatic ecosystems through processes such as removal of particles, nutrient cycling, and biodeposition (Milke and Ward, 2003).

Invasive species have the potential to promote changes in the structure of aquatic ecosystems because of their rapid establishment and high densities. Zebra mussel Dreissena polymorpha (Pallas, 1771) (Bivalvia, Dreissenidae) is an example of an invasive bivalve altering ecosystem and community structure of lakes and rivers (Naddafi et al., 2007). This mussel is invasive in many freshwater ecosystems in Europe and North America. In places where dense populations of $D$. polymorpha were established, phytoplankton biomass was changed (Holland, 1993; Fahnenstiel et al., 1995; Caraco et al., 1997), as well as the seston composition (Vanderploeg et al., 1996; Smith et al., 1998; Strayer et al., 1999).

Studies have pointed out the fact that zebra mussel can change cyanobacteria density and promote the occurrence of cyanobacteria blooms (Lavrentyev et al., 1995; Vanderploeg et al., 2001; Nicholls et al., 2002). Cyanobacteria dominance is a global problem, especially in freshwater ecosystems, due to bloom formation and toxin production. Poisoning and even death of wild animals, domestic animals and humans may be linked to cyanobacteria toxicity (Carmichael et al., 2001). Nevertheless, the effects of zebra mussel on cyanobacteria densities remain contradictory. Various studies have documented that zebra mussel filtration promoted the decrease of cyanobacteria densities (Bastviken et al., 1998; Dionisio-Pires and van Donk, 2002). Other studies have found that the presence of zebra mussel in invaded ecosystems has led to increased cyanobacteria densities (Lavrentyev et al., 1995; Vanderploeg et al., 2001; Juhel et al., 2006; Naddafi et al. 2007).

Most studies concerning bivalve filtration were carried out using laboratory cultures of single-celled cyanobacteria. However, bloom forming cyanobacteria occur mainly as colonies or filaments in nature. Colonies eventually formed in laboratory conditions are usually small and without mucilage with the predominance of single cells (Dionisio-Pires and van Donk, 2002). Laboratory studies under controlled conditions of mussel feeding in the presence of colonial and filamentous cyanobacteria are scarce (Dionisio-Pires et al., 2005; Bontes et al., 2007). Studies performed with natural seston containing natural colonies of Microcystis have found that D. polymorpha promoted the increase of cyanobacteria densities by low filtration on colonies and their rejection as pseudofeces (Baker et al., 1998; Makarewicz et al., 1999; Vanderploeg et al., 2001; Nicholls et al., 2002; Naddafi et al., 2007). Natural colonies of Microcystis are usually large, therefore non-preferentially ingested (Vanderploeg et al., 2001).
The invasive bivalve Limnoperna fortunei (Dunker, 1857) (Bivalvia, Mytilidae), known as golden mussel, has a similar behavior to zebra mussel $D$. polymorpha. Since its invasion in South America in 1991, golden mussel has been proliferating and dominating aquatic ecosystems such as rivers, lakes, and reservoirs (Mansur et al., 2004; Darrigran and Mansur, 2006). This invasive species has a great potential to change the structure of invaded environments due to its ability to quickly proliferate and turn into massive populations.

Studies on L. fortunei impacts on phytoplankton biomass and food chain structure are rare (Boltovskoy et al., 2009; Molina et al. 2010). In a previous study, the hypothesis was tested that $L$. fortunei prefer to intake non-toxic phytoplankton (diatom $N$. palea and non-toxic strain of $M$. aeruginosa) and reject toxic cyanobacteria (toxic strain of M. aeruginosa) as pseudofeces (Gazulha et al., 2007). Golden mussel has shown preferential acceptance of Microcystis, regardless of being toxic or non-toxic, and great rejection of diatom as pseudofeces. The long-term grazing experiment showed there were no negative effects of toxic Microcystis on filtration and survival of golden mussel suggesting other factors than toxicity influence selective feeding of golden mussel (Gazulha, 2010).

The aim of this study was to compare filtration rates and the feeding behavior of golden mussel (L. fortunei) when exposed to food of different sizes and shapes: single-celled (M. aeruginosa), colonial (M. aeruginosa), and filamentous (natural bloom of Planktothrix sp.) cyanobacteria. The first hypothesis holds that golden mussel filter more efficiently smaller particles, which could be more easily assimilated by bivalve filtering apparatus. The second hypothesis sustains that L. fortunei filter more efficiently rounded shapes, such as colonies of Microcystis, which would be more easily ingested than length filamentous cyanobacteria. To test these hypotheses non-toxic food from the same nutritional group (i.e. cyanobacteria) was used to avoid possible effects of these factors in the results.

\section{Material and Methods}

\subsection{L. fortunei sampling and acclimation}

Golden mussels used in the experiments were collected from the Guaíba Lake, southern Brazil. In the laboratory, mussels were kept in an aquarium containing natural water from the sampling site to acclimatize for 24 hours. The aquarium was kept in acclimatized room $\left(24{ }^{\circ} \mathrm{C}\right)$ at constant aeration. These specimens selected for the experiments were apparently healthy as indicated by their filtration activity. The mussels were of similar sizes (approximately $30 \mathrm{~mm}$ ) so as to avoid possible differences in filtration rates related to their sizes. Selected mussels were washed and brushed to remove microorganisms attached to their shells and were placed in flasks containing mineral water for a 4 hours period without food to evacuate and clear their guts. 


\subsection{Cyanobacteria strains}

Non-toxic (NPCD-1) strain of Microcystis aeruginosa was provided by the Laboratory of Ecophysiology and Toxicology of Cyanobacteria from the Federal University of Rio de Janeiro, Brazil and cultivated in ASM-1 growth medium. NPCD-1 strain was batch-cultured in $250 \mathrm{~mL}$ Erlenmeyer flasks in a $25^{\circ} \mathrm{C}$ incubator with a $14: 10 \mathrm{~h}$ light: dark cycle and light intensity of 2000 lux. Bloom of Planktothrix sp. was sampled from the Guaíba Lake. Non-toxicity of Planktothrix natural bloom was confirmed by analyses of microcystins (MC-LR) using ELISA test kit $\left(\right.$ Beacon $\left.^{\circledR}\right)$.

\subsection{Filtration, ingestion and pseudofeces production rates}

The feeding behavior of golden mussel was evaluated by assessing the Filtration Rate (FR) or Clearance Rate (CR), Ingestion Rate (IR), and Pseudofeces Production Rate (PPR). FR was assessed by considering the amount of particles captured by the mussels. IR equaled FR less PPR. Pseudofeces are the filtered particles agglomerated with mucus which are expelled periodically by inhalant opening, i.e. particles filtered but not ingested. Therefore, the filtration rate equalled the ingestion rate only if no pseudofeces were produced.

Filtration rates of golden mussel were estimated using the following equation based on Coughlan (1969) (Equation 1):

$$
\mathrm{FR}=\mathrm{V}\left(\ln \left(\mathrm{C}_{\mathrm{o}} / \mathrm{C}_{\mathrm{t}}\right)-\ln \left(\mathrm{C}_{\mathrm{o}}{ }_{\mathrm{o}} / \mathrm{C}_{\mathrm{t}}{ }_{\mathrm{t}}\right)\right) / \mathrm{NT}
$$

where FR is the filtration rate (mL.mussel ${ }^{-1} \cdot h^{-1}$ or $\left.\mathrm{mL} \cdot \mathrm{mgDW}^{-1} \cdot \mathrm{h}^{-1}\right), \mathrm{V}$ is the volume of water in the experimental chamber ( $\mathrm{mL}), \mathrm{N}$ is the number of mussels per chamber or their dry weight $(\mathrm{mgDW}), \mathrm{T}$ is the total filtration time (h), $\mathrm{C}_{0}$ is the food concentration $\left(\mathrm{mm}^{3} \cdot \mathrm{L}^{-1}\right)$ at $\mathrm{T}=0, \mathrm{C}_{\mathrm{t}}$ is the food concentration at time $\mathrm{T}$ in flasks with mussel, $\mathrm{C}^{\prime}{ }_{0}$ is the food concentration in the control flask (without mussel) at $\mathrm{T}=0$ and the $\mathrm{C}^{\prime}{ }_{0}$ is the food concentration in the control flask at time $\mathrm{T}$.

The samples taken to estimate food concentration $\left(\mathrm{mm}^{3} \cdot \mathrm{L}^{-1}\right)$ were preserved in $1 \%$ Lugol solution and counted in a Sedgewick-Rafter chamber. Biovolume $\left(\mathrm{mm}^{3}\right)$ was calculated according to Hillebrand et al. (1999). Mussel tissue was removed from shells and oven-dried at $60{ }^{\circ} \mathrm{C}$ for 48 hours to assess the dry weight (mgDW).

\subsection{Experimental design}

Limnoperna fortunei was fed on non-toxic strains of single-celled, colonial, and filamentous cyanobacteria to evaluate the effects of size and shape on selective feeding.
This experiment was conducted using 3 types of food (Table 1) with 10 replicates each at an initial biovolume of $2 \mathrm{~mm}^{3}$. $\mathrm{L}^{-1}$. A $60 \mu \mathrm{m}$-plankton net was used to separate colonial from single Microcystis in a NPCD-1 strain. Each replicate was performed in a flask containing $400 \mathrm{~mL}$ of mineral water, food suspension and one mussel. Flasks were kept in an acclimatized room $\left(24^{\circ} \mathrm{C}\right)$ during total filtration time ( 1 hour) and were gently stirred every 15 minutes to keep food particles in suspension. Flasks were prepared in the same conditions, with no mussel, to assess possible phytoplanktonic growth during filtration time. Each specimen of golden mussel was monitored under a stereomicroscope during total filtration time (1 hour). The number of feces and pseudofeces released by the mussels was scored and expressed as events $\mathrm{h}^{-1}$.

A method was applied in the present study to estimate accurately pseudofaeces production by mussels (Gazulha, 2010). All feces and pseudofeces produced were captured using a micropipette in the moment of expelling and preserved in $1 \%$ Lugol solution. To assess it, the PPRs samples were disintegrated in an ultrasound Bandelin Sonorex RK $100 \mathrm{H}$ for 10 minutes to separate cells from the mucus and counted in a Sedgewick-Rafter chamber $\left(\mathrm{mm}^{3} \cdot \mathrm{L}^{-1}\right)$. Applying the ultrasound was efficient to separate cells from the mucus and did not damage the cells. Individuals used in this experiment kept their filtering ability with the valves opened and the inhalant siphon exposed during the total filtration time (1 hour).

\subsection{Statistical analysis}

Data on golden mussel feeding were submitted to analyses of variance (One-way ANOVA) with Tukey's test for multiple comparison to detect significant differences ( $\alpha=0.05$ ) of FRs, IRs and PPRs among food types. Tukey's test was performed after confirming the normality of data using Kolmogorov-Smirnov (KS) test $(\alpha=0.05)$.

\section{Results}

FRs of golden mussel varied from 404.6 to $848 \mathrm{~mL}$. mussel $^{-1} \cdot \mathrm{h}^{-1}$. The mean value was $606.6 \mathrm{~mL} \cdot$ mussel $^{-1} \cdot \mathrm{h}^{-1}$. Mean FRs slightly varied from 562.1 on filamentous to 663.2 mL.mussel ${ }^{-1} \cdot \mathrm{h}^{-1}$ on colonial Microcystis $(\mathrm{p}>0.05$; Figure 1). L. fortunei FRs in relation to body mass ranged from 6.8 to $26.1 \mathrm{~mL} \cdot \mathrm{mgDW}^{-1} \cdot \mathrm{h}^{-1}$ at a mean value of $14.8 \mathrm{~mL} \cdot \mathrm{mgDW}^{-1} \cdot \mathrm{h}^{-1}$. There were no significant differences on mussel FRs among different types of food ( $p>0.05$ ). Mean values barely varied from $13.7 \mathrm{~mL} \cdot \mathrm{mgDW}^{-1} \cdot \mathrm{h}^{-1}$ when mussel fed on filamentous Planktothrix to $16.2 \mathrm{~mL}$. $\mathrm{mgDW}^{-1} \cdot \mathrm{h}^{-1}$ when it fed on colonial Microcystis (Figure 1).

Table 1. Food types (species, strain, shape, and size) used in Limnoperna fortunei feeding experiment.

\begin{tabular}{lccc}
\hline \multicolumn{1}{c}{ Cyanobacteria species } & Strain & Shape & Size (GLD*) \\
\hline 1) Non-toxic Microcystis aeruginosa & NPCD-1 & Single cells & $3.7 \mu \mathrm{m}$ \\
2) Non-toxic Microcystis aeruginosa & NPCD-1 & Colonial & $60-100 \mu \mathrm{m}$ \\
3) Non-toxic bloom of Planktothrix sp. & NB & Filamentous & $100-1000 \mu \mathrm{m}$ \\
\hline
\end{tabular}

*Greatest Linear Dimension. 


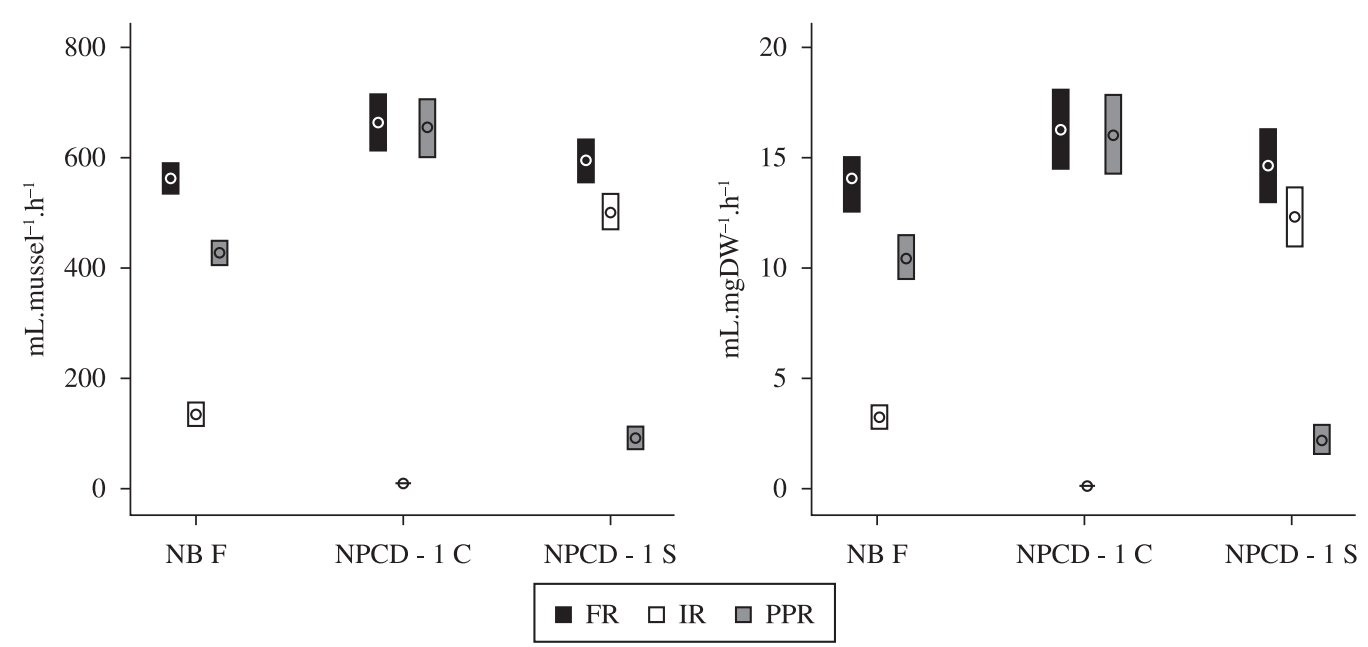

Figure 1. Filtration Rates (FR), Ingestion Rates (IR), and Pseudofeces Production Rates (PPR) of L. fortunei (mL.mussel ${ }^{-1} \cdot \mathrm{h}^{-1}$ and $\left.\mathrm{mL} \cdot \mathrm{mgDW}^{-1} \cdot \mathrm{h}^{-1}\right)$ in the presence of filamentous, colonial, and single-celled cyanobacteria $($ symbol $=$ mean, and bar $=\mathrm{SE})$. Natural bloom of filamentous Planktothrix (NB F), colonial M. aeruginosa (NPCD-1 C), and single-celled M. aeruginosa (NPCD-1 S).

IRs ranged from 7.1 to $610.5 \mathrm{~mL} \cdot \mathrm{musse}^{-1} \cdot \mathrm{h}^{-1}$. Golden mussel ingestion greatly varied among food types $(\mathrm{p}<0.05$; Figure 1). Single cells of Microcystis were highly ingested, at a mean rate of $502.2 \mathrm{~mL}$.mussel ${ }^{-1} \cdot \mathrm{h}^{-1}$. Filamentous Planktothrix were less accepted than single cells, and were ingested at a rate of $135.1 \mathrm{~mL} \cdot \mathrm{mussel}^{-1} \cdot \mathrm{h}^{-1}$. Colonial Microcystis were scarcely ingested at a rate of $10.3 \mathrm{~mL} \cdot \mathrm{mussel}^{-1} \cdot \mathrm{h}^{-1}$. In terms of body mass, IRs varied from 0.2 to 18 . $\mathrm{mL}$. $\mathrm{mgDW}^{-1} \cdot \mathrm{h}^{-1}$ and the mean value was $5.3 \mathrm{~mL} \cdot \mathrm{mgDW}^{-1} \cdot \mathrm{h}^{-1}$. Single cells were preferentially ingested by golden mussel and the mean rate was $12.3 \mathrm{~mL} \cdot \mathrm{mgDW}^{-1} \cdot \mathrm{h}^{-1}$, while colonies were ingested at a very low rate of $0.3 \mathrm{~mL} \cdot \mathrm{mgDW}^{-1} \cdot \mathrm{h}^{-1}$ ( $\mathrm{p}<0.05$; Figure 1). L. fortunei preferentially ingested single-celled and greatly rejected filamentous and colonial cyanobacteria.

PPRs varied from 42.7 to $838.7 \mathrm{~mL} \cdot \mathrm{mussel}^{-1} \cdot \mathrm{h}^{-1}$. Golden mussel greatly rejected colonial Microcystis $(\mathrm{p}<0.05)$ at a mean rate of $652.9 \mathrm{~mL} \cdot \mathrm{mussel}^{-1} \cdot \mathrm{h}^{-1}$ (Figure 1). Filamentous cyanobacteria were rejected at a mean rate of $427 \mathrm{~mL}$. mussel ${ }^{-1} \cdot \mathrm{h}^{-1}$. Single-celled Microcystis was the food type which was less rejected as pseudofeces $(\mathrm{p}<0.05)$ at a mean rate of $92.4 \mathrm{~mL} \cdot \mathrm{mussel}^{-1} \cdot \mathrm{h}^{-1}$ (Figure 1). PPRs in body mass varied from 0.9 to $25.8 \mathrm{~mL} \cdot \mathrm{mgDW}^{-1} \cdot \mathrm{h}^{-1}$. Colonial Microcystis were most rejected by golden mussel at a mean rate of $15.9 \mathrm{~mL} \cdot \mathrm{mgDW}^{-1} \cdot \mathrm{h}^{-1}$, while singlecelled Microcystis was hardly rejected at a mean rate of $2.3 \mathrm{~mL} \cdot \mathrm{mgDW}^{-1} \cdot \mathrm{h}^{-1}(\mathrm{p}<0.05$; Figure 1$)$.

Golden mussel pseudofeces releasing ranged from 16 to 233 events. $\mathrm{h}^{-1}$, and the mean value was 106.6 events. $\mathrm{h}^{-1}$. Both colonial Microcystis and filamentous cyanobacteria were greatly rejected as pseudofeces ( $<<0.05$; Figure 2$)$. Golden mussel when fed on single-celled Microcystis expelled a very low quantity of pseudofeces when compared to colonial and filamentous ( $\mathrm{p}<0.05$; Figure 2). Feces released by golden mussel varied from 1 to 4 events. ${ }^{-1}$ and did not significantly change among different types of food ( $\mathrm{p}>0.05$; Figure 2).

\section{Discussion}

FRs of golden mussel in the presence of single-celled, colonial, and filamentous food were similar. Despite this, there was a great difference between IRs and PPRs among food types. Single cells were widely accepted as food, while filamentous and colonial cyanobacteria were massively expelled as pseudofeces and barely ingested. The first hypothesis was accepted given that golden mussel prefers to ingest smaller particles, such as single cells of Microcystis. The second hypothesis was rejected, since filamentous were preferentially ingested than colonial cyanobacteria, although filamentous Planktothrix was highly rejected, as well as Microcystis colonies, when compared to single cells.

Some studies performed with other bivalves, especially Dreissena, indicate that mussels preferentially ingest smaller particles. Vanderploeg et al. (2001) have shown zebra mussel predominantly ingested small colonies and single cells of $M$. aeruginosa from laboratory cultures, while Microcystis colonies from natural seston were mostly rejected. Baker et al. (2000) have revealed that zebra mussel when fed on a mixture of Scenedesmus and Microcystis ingested preferentially cyanobacteria, while green algae were commonly incorporated into a mucus string and rejected as pseudofeces. Smaller particles, such as single cells of Microcystis, were ingested and larger ones, such as Scenedesmus, were rejected. Nadafi et al. (2007) studying the effects of Dreissena on natural seston have shown that zebra mussel greatly expelled in pseudofeces large phytoplankton.

In experiments on the impact of Dreissena on natural seston from the Hudson River, Bastviken et al. (1998) 

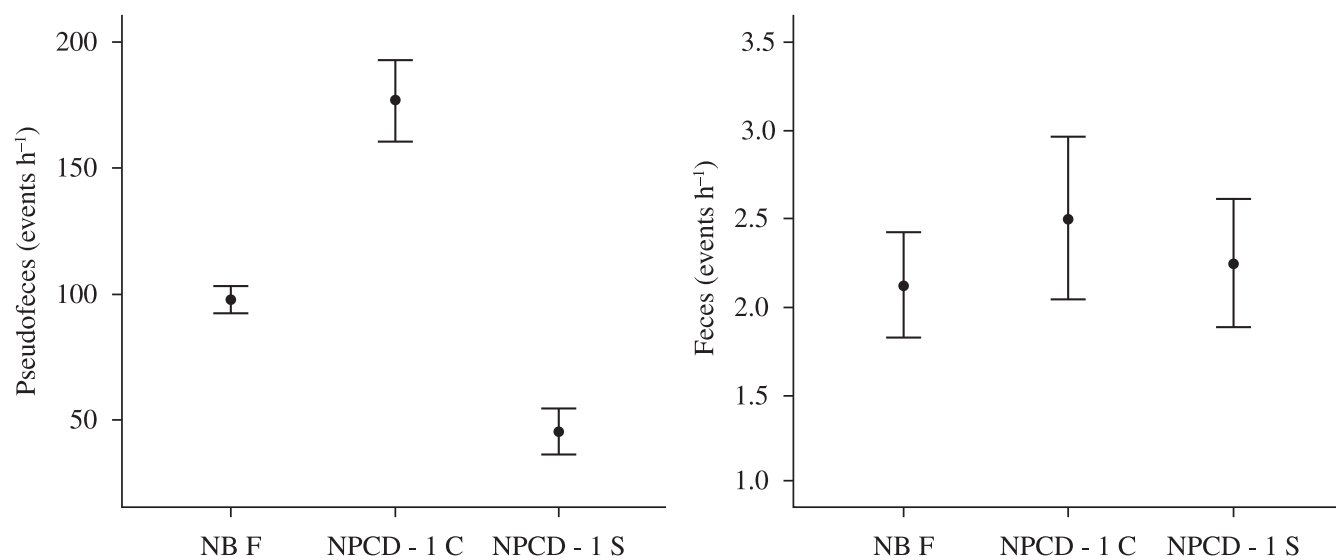

Figure 2. L. fortunei pseudofeces and feces (events. $\mathrm{h}^{-1}$ ) in the presence of filamentous, colonial, and single-celled cyanobacteria $($ symbol = mean, and bar = SE). Natural bloom of filamentous Planktothrix $(\mathrm{NB} F)$, colonial M. aeruginosa (NPCD-1 C), and single-celled M. aeruginosa (NPCD-1 S).

found that FRs on different phytoplankton species were similar and even large filaments or colonies were cleared. Nevertheless, their rejection as pseudofeces varied greatly. They also observed that zebra mussel ingested preferentially single-celled Microcystis while Microcystis colonies were immensely rejected as pseudofeces. Bastviken et al. (1998) also found similar FRs on different sizes and shapes of food, whereas PPRs varied hugely.

L. fortunei preferably ingested Microcystis cells, regardless of being toxic or not, and highly expelled diatom Nitzschia palea as undesirable food (Gazulha, 2010). Low ingestion of Nitzschia was attributed to their larger cell volume in comparison to Microcystis, as well as to stiff silicate frustules of diatoms which would not make them a suitable food. Similar results were registered in the present study wherein larger particles, such as colonial and filamentous, were commonly expelled while small single cells were widely accepted by golden mussel.

There are few experiments focusing on ingestion of filamentous algae by bivalves (Dionisio-Pires et al., 2005; Bontes et al., 2007). Bontes et al. (2007) have studied feeding of bivalve Anodonta anatina on filamentous (Planktothrix) and colonial (Microcystis) cyanobacteria. They have concluded that mussels can filter and ingest colonial, as well as larger filamentous cyanobacteria regardless of their toxicity. They have also observed high pseudofeces production by Anodonta when fed with filamentous Planktothrix suggesting this species is not a very suitable food.

In a feeding experiment using zebra mussel, DionisioPires et al. (2005) registered high FRs on single-celled, colonial and filamentous cyanobacteria. However, a significant difference was not observed concerning pseudofeces releasing among different cyanobacteria. Present results on golden mussel corroborate with zebra mussel data since significant differences of FRs were not observed on different cyanobacteria sizes and shapes. However, our data disagrees since high rejection of filamentous and colonial cyanobacteria was found. The absence of differences on pseudofeces releasing observed by Dionisio-Pires et al. (2005) could be related to the method used to evaluate the pseudofeces production. They evaluated pseudofeces after the filtration time, although mussels actually keep releasing pseudofeces while they are filtering, which could have led to an underestimation of excreted products.

There are many differences among methods used to estimate feeding of mussels, making it difficult to compare results. Several studies do not effectively separate filtered or cleared from ingested and rejected food making comparisons among studies not always valid. In the present study, feeding activity of each $L$. fortunei specimen was carefully observed under a stereomicroscope. All feces and pseudofeces released during total filtration time were collected and quantified, which makes data more accurate.

The selective feeding of golden mussel could promote the return of non-selected food to sediments and favor species rejected that possibly remain alive in the bottom of systems, as suggested by Baker et al. (1998). The present results have shown feeding selection of golden mussel does not occur during clearing, but in the labial palps and gills after the filtration of particles. Some studies have registered that food particles have remained alive after being expelled by mussels. Nadafi et al. (2007) have observed that colonial cyanobacteria Gloeotrichia echinulata were viable after rejection by zebra mussel and could return unharmed to the water column and migrate vertically due to their possession of gas vacuoles. Baker et al. (1998) showed that pseudofeces from zebra mussel containing diatoms can resuspend under turbulent mixing during seasonal circulation and autumn turnover. They also observed that algae from zebra mussel pseudofeces when cultured in a laboratory continued to grow.

The impacts of mussels on trophic chains will probably be related to the system mixing regime (Bastviken et al., 1998). In well mixed systems, phytoplankton would not be able to avoid contact with mussels. On the other hand, in systems with low mixing, phytoplankton would be able to avoid this contact by locomotion or buoyancy regulation. 
Thus, mussel impact on the plankton community is dependent on the ecosystem mixing regime among other indirect factors, such as light and nutrients (Bastviken et al., 1998).

L. fortunei is an efficient filter-feeding indicating its potential in removing particles from the water column and causing great changes to the trophic structure of food chains. The presence of golden mussel may result in a dominance of large phytoplankton (colonies and filaments) over small phytoplankton in ecosystems where this invasive bivalve occurs in massive densities.

\section{Conclusion}

The impacts of golden mussel on planktonic communities may be high, since this invasive bivalve occurs in massive densities on invaded ecosystems and their filtration rates are high when compared with other freshwater invasive bivalves. Moreover, L. fortunei has the ability to select food particles, and thus promote the dominance of certain species of plankton in aquatic ecosystems. The presence of mussel could lead to a reduction in single cells (Microcystis), and favor an increase in colonial (Microcystis) and filamentous (Planktothrix) cyanobacteria. Golden mussel has the potential to remove toxic cells (Microcystis), however this potential would be reduced in cyanobacteria blooms, where colonial forms which are preferentially rejected by $L$. fortunei, are predominant. In this case, the presence of this invasive bivalve could also enhance the occurrence of blooms by rejection of colonial and filamentous cyanobacteria in pseudofeces.

Acknowledegments - We would like to thank the National Council for Scientific and Technological Development (CNPq) for providing a doctorate fellowship to VG.

\section{References}

BAKER, SM., LEVINTON, JS., KURDZIEL JP. and SHUMWAY, SE., 1998. Selective feeding and biodeposition by zebra mussels and their relation to changes in phytoplankton composition and seston load. Journal of Shellfish Research, vol. 17, p. 1207-1213.

BAKER, SM., LEVINTON, JS. and WARD, JE., 2000. Particle transport in the zebra mussel, Dreissena polymorpha (Pallas). Biological Bulletin, vol. 199, p. 116-125. PMid:11081710. http:// dx.doi.org/10.2307/1542871

BASTVIKEN, DTE., CARACO, NF. and COLE, JJ., 1998. Experimental measurements of zebra mussel (Dreissena polymorpha) impacts on phytoplankton community composition. Fresh Biology, vol. 39 , p. 375-386.

BOLTOVSKOY, D., KARATAYEV, A., BURLAKOVA, L., CATALDO, D., KARATAYEV, V., SYLVESTER, F. and MARIÑELARENA, A., 2009. Significant ecosystem-wide effects of the swiftly spreading invasive freshwater bivalve Limnoperna fortunei. Hydrobiologia, p. 1-14.

BONTES, BM., VERSCHOOR, AM., PIRES, LMD., VAN DONK, E. and IBELINGS, BW., 2007. Functional response of Anodonta anatina feeding on a green alga and four strains of cyanobacteria, differing in shape, size and toxicity. Hydrobiologia, vol. 584, p. 191-204. http://dx.doi.org/10.1007/s10750-007-0580-2
CARACO, NF., COLE, JJ., RAYMOND, PA., STRAYER, DL., PACE, ML., FINDLAY, SEG. and FISCHER, DT., 1997. Zebra mussel invasion in a large, turbid river: phytoplankton response to increased grazing. Ecology, vol. 78, p. 588-602.

CARMICHAEL, WW., AZEVEDO, S., AN, JS., MOLICA, RJR., JOCHIMSEN, EM., LAU, S., RINEHART, KL., SHAW, GR. and EAGLESHAM, GK., 2001. Human fatalities from cyanobacteria: chemical and biological evidence for cyanotoxins. Environmental Health Perspectives, vol. 109, p. 663-668. PMid:11485863. PMCid:1240368. http://dx.doi.org/10.1289/ehp.01109663

COUGHLAN, J., 1969. Estimation of filtering rate from clearance of suspensions. Marine Biology, vol. 2, p. 356-359. http://dx.doi. org/10.1007/BF00355716

DARRIGRAN, G. and MANSUR, MCD., 2006. Distribución, abundancia y dispersión. In DARRIGRAN, G. and DAMBORENEA, C., (Eds). Bio-invasión del mejillón dorado en el continente americano. La Plata: Universidad Nacional de La Plata. p. 93-112.

DIONISIO-PIRES, LM., BONTES, BM., Van-DONK, E. and IBELINGS, BW., 2005. Grazing on colonial and filamentous, toxic and non-toxic cyanobacteria by the zebra mussel Dreissena polymorpha. Journal of Plankton Research, vol. 27, p. 331-339. http://dx.doi.org/10.1093/plankt/fbi008

DIONISIO PIRES, LM. and Van DONK, E., 2002. Comparing grazing by Dreissena polymorpha on phytoplankton in the presence of toxic and non-toxic cyanobacteria. Fresh Biology, vol. 47, p. 1855-1865. http://dx.doi.org/10.1046/j.1365-2427.2002.00933.x

FAHNENSTIEL, GL., BRIDGEMAN, TB., LANG, GA., MCCORMICK, MJ. and NALEPA, TF., 1995. Phytoplankton productivity in Saginaw Bay, Lake Huron: effects of zebra mussel (Dreissena polymorpha) colonization. Journal of Great Lakes Research, vol. 21, p. 465-475.

GAZULHA, V., 2010. O mexilhão dourado Limnoperna fortunei (Dunker, 1857) na presença de cianobactérias: taxas de filtração, comportamento alimentar e sobrevivência. Porto Alegre: Universidade Federal do Rio Grande do Sul. 104 p. Tese de Doutorado em Recursos Hídricos e Saneamento Ambiental.

GAZULHA, V., MANSUR, MCD., PIMENTEL, J. and CYBIS, LF., 2007. Filtration rates of the invasive bivalve Limnoperna fortunei (Dunker, 1857) in the presence of toxic cyanobacteria and nontoxic phytoplankton. In Proceedings of the VII International Conference on Toxic Cyanobacteria; 2007; Rio de Janeiro. Rio de Janeiro. p. 41

HILLEBRAND, H., DURSELEN, CD., KIRSCHTEL, D., POLLINGHER, U. and ZOHARY, T., 1999. Biovolume calculation for pelagic and benthic microalgae. Journal of Phycology, vol. 35, p. 403-424. http://dx.doi.org/10.1046/j.1529-8817.1999.3520403.x

HOLLAND, RE., 1993. Changes in planktonic diatoms and water transparency in Hatchery Bay, bass-island area, western Lake Erie since the establishment of the zebra mussel. Journal of Great Lakes Research, vol. 19, p. 617-624. http://dx.doi.org/10.1016/ S0380-1330(93)71245-9

JUHEL, G., DAVENPORT, J., O'HALLORAN, J., CULLOTY, S., RAMSAY, R., JAMES, K., FUREY, A. and ALLIS, O., 2006. Pseudodiarrhoea in zebra mussels Dreissena polymorpha (Pallas) exposed to microcystins. Journal of Experimental Biology, vol. 209, p. 810-816. PMid:16481570. http://dx.doi.org/10.1242/jeb.02081

LAVRENTYEV, PJ., GARDNER, WS., CAVALETTO, JF. and BEAVER, JR., 1995. Effects of the zebra mussel (Dreissena polymorpha Pallas) on protozoa and phytoplankton from 
Saginaw Bay, Lake Huron. Journal of Great Lakes Research, vol. 21, p. 545-557. http://dx.doi.org/10.1016/S0380-1330(95)71065-6

MAKAREWICZ, JC., LEWIS, TW. and BERTRAM, P., 1999. Phytoplankton composition and biomass in the offshore waters of Lake Erie: pre- and post-Dreissena introduction (1983-1993). Journal of Great Lakes Research, vol. 25, p. 135-148. http:// dx.doi.org/10.1016/S0380-1330(99)70722-7

MANSUR, MCD., CARDOSO, FR., RIBEIRO, LA., SANTOS, CP., THORMANN, BM., FERNANDES, FC. and RICHINITTI, LMZ. 2004. Distribuição e consequências após cinco anos da invasão do mexilhão-dourado, Limnoperna fortunei no estado do Rio Grande do Sul, Brasil (Mollusca, Bivalvia, Mytilidae). Biociências, vol. 12, p. 165-172.

MILKE, LM., and WARD, JE., 2003. Influence of diet on preingestive particle processing in bivalves II. Residence time in the pallial cavity and handling time on the labial palps. Journal of Experimental Marine Biology and Ecology, vol. 293, p. 151-172. http://dx.doi.org/10.1016/S0022-0981(03)00217-X

MOLINA, FR., PAGGI, JC. and DEVERCELLI, M., 2010. Zooplanktophagy in the natural diet and selectivity of the invasive mollusk Limnoperna fortunei. Biological Invasions, vol. 12, no. 6, p. 1647. http://dx.doi.org/10.1007/s10530-009-9578-1

NADDAFI, R., PETTERSSON, K. and EKLOV, P., 2007. The effect of seasonal variation in selective feeding by zebra mussels (Dreissena polymorpha) on phytoplankton community composition. Fresh Biology, vol. 52, p. 823-842. http://dx.doi. org/10.1111/j.1365-2427.2007.01732.x
NICHOLLS, KH., HEINTSCH, L. and CARNEY, E., 2002. Univariate step-trend and multivariate assessments of the apparent effects of $\mathrm{P}$ loading reductions and zebra mussels on the phytoplankton of the Bay of Quinte, Lake Ontario. Journal of Great Lakes Research, vol. 28, p. 15-31. http://dx.doi.org/10.1016/ S0380-1330(02)70559-5

SMITH, TE., STEVENSON, RJ., CARACO, NF. and COLE, JJ., 1998. Changes in phytoplankton community structure during the zebra mussel (Dreissena polymorpha) invasion of the Hudson River (New York). Journal of Plankton Research, vol. 20, p. 15671579. http://dx.doi.org/10.1093/plankt/20.8.1567

STRAYER, DL., CARACO, NF., COLE, JJ., FINDLAY, S. and PACE, ML., 1999. Transformation of freshwater ecosystems by bivalves. BioScience, vol. 49, p. 19-27. http://dx.doi. org/10.2307/1313490

VANDERPLOEG, HA., LIEBIG, JR. and GLUCK, AA., 1996. Evaluation of different phytoplankton for supporting development of zebra mussel larvae (Dreissena polymorpha): The importance of size and polyunsaturated fatty acid content. Journal of Great Lakes Research, vol. 22, p. 36-45. http://dx.doi.org/10.1016/ S0380-1330(96)70932-2

VANDERPLOEG, HA., LIEBIG, JR., CARMICHAEL, WW., AGY, MA., JOHENGEN, TH., FAHNENSTIEL, GL. and NALEPA, TF., 2001. Zebra mussel (Dreissena polymorpha) selective filtration promoted toxic Microcystis blooms in Saginaw Bay (Lake Huron) and Lake Erie. Canadian Journal of Fisheries and Aquatic Sciences, vol. 58, p. 1208-1221. http://dx.doi. org/10.1139/f01-066 
